\title{
Does Rotational Grazing Based on Leaf Expansion Duration Modify Grazing Behavior and Feed Intake of Beef Heifers on Natural Grassland?
}

\author{
Bruno Castro Kuinchtner ${ }^{1}$, Fernando Luiz Ferreira de Quadros $^{2}$, Fernanda Maurer Taschetto ${ }^{1}$, \\ Gabriela Machado Dutra ${ }^{1}$, Liane Seibert ${ }^{1}$, Fernando Ongaratto ${ }^{1} \&$ Pedro Trindade Casanova ${ }^{1}$ \\ ${ }^{1}$ Natural Pasture Ecology Laboratory (LEPAN), Universidade Federal de Santa Maria, Santa Maria, Rio Grande \\ do Sul, Brazil \\ ${ }^{2}$ Titular Professor of Animal Sciences, Universidade Federal de Santa Maria, Santa Maria, Rio Grande do Sul, \\ Brazil \\ Correspondence: Bruno Castro Kuinchtner, Natural Pasture Ecology Laboratory (LEPAN), Universidade Federal \\ de Santa Maria, Santa Maria, Rio Grande do Sul, 97105-900, Brazil. Tel: 55-55-99985-1200. E-mail: \\ brunobck@hotmail.com
}

Received: July 5, 2021

Accepted: August 13, $2021 \quad$ Online Published: September 15, 2021

doi:10.5539/jas.v13n10p85

URL: https://doi.org/10.5539/jas.v13n10p85

The research is financed by the National Counsel of Technological and Scientific Development (CNPq).

\begin{abstract}
Grasslands develop a multifunctional role to humanity, with unique fauna and flora, besides being the primary feed source for herbivores. However, grasslands are usually considered a low-efficiency production system, often converted into other land uses such as crops and forestation (e.g., south Brazil). This study aimed to evaluate the effect of two rest intervals between grazing occupations in rotational grazing on the grazing behavior and feed intake of beef heifers. Two grazing intervals, 375 and 750 DD (degree-days) were used; based on the cumulative thermal sum necessary for the leaf expansion of native grasses of two functional groups. The experiment was conducted as a completely randomized block design, with two treatments, three replications, and repeated measures over time. The grazing behavior was evaluated continuously for 18 hours $(7 \mathrm{a} . \mathrm{m}$. to $11 \mathrm{~h} 59$ p.m.). Herbage intake was estimated using an external marker $\left(\mathrm{Cr}_{2} \mathrm{O}_{3}\right)$ in four periods (one for each season). The green leaf mass was similar between treatments, with a mean of $40 \%$ of the pregrazing mass $\left(\mathrm{kg} \mathrm{DM} \mathrm{ha}^{-1}\right)$. On average grazing, time was $50 \%$ of the period, and the bite rate was 38.7 bites $\mathrm{min}^{-1}$. The number of daily meals was 6.5, with an average of 84 minutes for each meal. The number of feeding times (feeding stations by minute) visited was 6.4 . On average, there was a $2.23 \%$ difference in dry matter intake ( $\% \mathrm{BW})$ among seasons. Neither ingestive behavior or forage consumption of heifers was affected by the treatments, both maintain similar chemical composition on natural grassland.
\end{abstract}

Keywords: beef cattle, degree-days, management, pampa biome, thermal sum

\section{Introduction}

Natural grasslands are on the decline on a global scale (Bengtsson et al., 2019; Haddock \& Good, 2012). Some land uses (e.g., extensive grazing) are compatible with natural grassland functions but may not have the immediate economic return of more intensive land uses. There is a need to reconcile individual financial needs with the requirements of healthy functioning natural grasslands. One way to do this is to provide incentives that align long term sustainable land management decisions with a stable and competitive economic return (ELD Initiative, 2015).

To improve the competitiveness with other land uses (e.g., crops), management of both forage and grazing animals is the key for successful livestock operations. A good goal is to develop a grazing system that uses properly managed and well-adapted forages while, at the same time, meeting the nutrient requirements of the animals. Various grazing management tools are available for beef cattle farmers to use forage resources more effectively (e.g., forage allowance, adjustment of stocking rate) and compete with other land uses such as 
farming (Martín et al., 2021; Carvalho \& Batello, 2009). Although the management tools mentioned above have already been evaluated, further research is needed to understand the interrelationships of grazing behavior, dietary quality, forage intake, and sward structure. Methods of modifying behavior to control feed intake that improve efficiency or reduce stress could significantly contribute to the livestock industry (Brem et al., 2012; Da Trindade et al., 2016).

The leaf elongation duration marks a period in which both the photosynthetic efficiency and the nutritional value of the leaf blade reach their peak. Leaf elongation duration is regulated by the accumulation of temperatures just like the phyllochron (Skinner \& Nelson, 1995). This characteristic is measured through a thermal sum expressed in degree-days (DD), being defined as the sum across days of the average between maximum and minimum daily temperatures (Carvalho et al., 2013; Provenza et al., 2004).

Our research hypothesis is that the use of ecophysiological characteristics to guide pasture management would allow a balance between sustainable production and conservation of natural grasslands with the animal production of this pastoral ecosystem. To make the most efficient use of plant and animal resources, it is essential to improve our understanding of the foraging strategies of livestock using these ecosystems (Gordon, 1995). Thus, our research hypothesis is that the use of ecophysiological characteristics to guide pasture management would allow a balance between sustainable production and conservation of natural grasslands with the animal production of this pastoral ecosystem.

In this context, our study evaluated two rest intervals between rotational grazing periods based on physiological characteristics of native grasses from the Pampa biome. This study used assessments of the ingestive behavior of two management proposals to compare with regional patterns of animal behavior in natural grasslands.

\section{Materials and Methods}

\subsection{Period, Treatments, and Experimental Area}

The experiment was conducted from June 2013 to April 2014 in an area of natural grassland representative of the Pampa biome (IBGE, 2004). The experimental area is located at the Federal University of Santa Maria (lat $29^{\circ} 43^{\prime} \mathrm{S}$ long $53^{\circ} 45^{\prime} \mathrm{W}$ ), at $95 \mathrm{~m}$ above sea level. The climate is classified as humid subtropical (Cfa), according Köppen. There are two soil types in the area: Typic Albaqualf on lowland areas and Rhodic Paleudalf on upper and slope areas (Streck et al., 2008). During the trial, the mean maximum temperature was $23.4{ }^{\circ} \mathrm{C}$, mean minimum temperature was $17.1{ }^{\circ} \mathrm{C}$, and mean rainfall was $135 \mathrm{~mm}$ per month, October being the driest $(54 \mathrm{~mm})$, and November the wettest month $(295 \mathrm{~mm}$ ) (see Appendix A).

The 23 ha experimental area (see Appendix B) was divided into six paddocks randomly assigned to one of the two treatments with three replicates in a randomised complete block design (paddock as experimental unit). Treatments consisted of two different thermal sums, 375 and 750 degree-days (DD), determining the length of paddock rest intervals between grazing events. The $375 \mathrm{DD}$ is the interval necessary for the elongation of 2.5 leaves of Axonopus affinis and Paspalum notatum, which are prostrate $\mathrm{C}_{4}$ grasses of the functional groups $\mathrm{A}$ and B (Quadros et al., 2006), with an average phyllochron of 150 DD (Eggers et al., 2004; Machado et al., 2013). The 750 DD represents the time for elongation of 2.2 leaves for tufted grasses such as Aristida laevis and Saccharum angustifolius, from functional groups C and D (Quadros et al., 2006), with phyllochron of 333 DD (Machado et al., 2013).

In treatment $375 \mathrm{DD}$, each replicate paddock of the $375 \mathrm{DD}$ treatment was subdivided into seven 0.5 ha grazing cells, while in the $750 \mathrm{DD}$ treatment, each replicates paddock was divided into eight 0.5 ha cells for grazing rotation resulting in a total of 45 grazing cells. Freshwater was provided in all grazing cells.

The occupation time of each grazing cell was a function of rest time (between the grazing periods) according to the following formula:

$$
\text { Occupation (degree-days) }=\frac{\text { Interval (DD) }}{\mathrm{N}^{0} \times \text { Grazing cells }-1 \text { (Cell in use) }}
$$

where, DD is the treatment DD, 1 is the number of paddocks in use and $N^{\circ}$. Grazing cells are either 7 or 8 for the 375 and 750 DD treatments, respectively. As an example, when the sum across days of the average between maximum and minimum daily temperatures reached around $62 \mathrm{DD}$ in the $375 \mathrm{DD}$, animals were changed to next cell. For 375 DD, it ranges from 4 to 7 occupation days, with a mean of 5.1, and for 750 DD, it ranges from 6 to 11 occupation days, with a mean of 7.9 days. Climate data were obtained from the National Meteorological Institute (INMET) in the automatic meteorological station of Santa Maria, RS.

Both treatments had a constant stocking rate and variable herbage allowance during the (June to September). From October to April a variable number of "put-and-take" heifers, with the same age as the test-animals, was 
used to adjust the stocking rate (SR), based on the proportion of leaves in the sward. The SR was adjusted so that $70 \%$ of the leaf mass could be removed and keep a residual mass of $1500 \mathrm{~kg} \mathrm{ha}^{-1}$ under rotational grazing. A grazing cell ( $0.5 \mathrm{ha})$ was selected in each paddock as the representative cell where all evaluations of aerial pasture biomass availability and plant component contribution were carried out.

Throughout the experiment over seven days there were assessments of ingestive behavior (Kozloski et al., 2006): June 13 (1); July 13 (2); September 13 (3); November 13 (4); February 14 (5); March 14 (6) and April 14 (7). Considering reasons of statistical analysis and ease of interpretation of the results, these dates were grouped into seasons, with dates 1 and 7 being autumn; dates 2 and 3, as winter; date 4, as spring, and dates 5 and 6 , as summer. The feed intake was estimated at four periods: June/13 (period 1), September/13 (period 2), December/13 (period 3), and April/14 (period 4), a period for each season.

\subsection{Experimental Animals, Supplements, and Grazing Management}

Thirty Angus beef heifers, average age of 8 months, mean initial body weight of $151 \pm 5.8 \mathrm{~kg}$ were used as test heifers.

Heifers were blocked by body weight into six groups with similar body weight. During winter, all heifers received daily supplementation of whole rice bran at 2:00 p.m. at a rate of $1.0 \%$ of body weight. Sanitary control of ticks and endoparasites was carried out when necessary, with pour-on (Fluazuron or Fipronil) or sprinkling shower (amitraz) and vaccination as required.

\subsection{Vegetation and Animal Measurements}

Herbage mass (HM; kg of dry matter (DM) per ha) was measured using a visual evaluation procedure of standards calibrated with a double-sampling technique (Haydock \& Shaw, 1975). Six $50 \times 50 \mathrm{~cm}$ quadrats samples clipped at ground level using were used to calibrate 20 visual estimates in each representative cell for each replicate paddock.

Biomass collected from clipped samples was weighed and divided into two subsamples. One was used to determine dry matter (DM) content, by drying in a forced-air oven at $55{ }^{\circ} \mathrm{C}$ for at least 72 hours, the second was used to separate structural components to obtain the percentage of green leaf lamina, pseudostem (grass species), dead material, and plant species other than grass (e.g., Cyperaceae, Asteraceae). Herbage allowance from green leaf blade $\left(\mathrm{kg} \mathrm{DM} / 100 \mathrm{~kg} \mathrm{day}^{-1}\right)$ was calculated using the mean leaf present in the pregrazing HM in each evaluation, divided by the number of occupation days and by the instantaneous stocking rate (ISR), multiplied by 100. Mean green leaf blade was calculated using the percentage of leaf by manual separation multiplied by herbage mass available in the cell (Kuinchtner et al., 2021).

ISR is the total body weight in an experimental group divided by the cell area. Mean stocking rate (MSR; $\mathrm{kg} \mathrm{ha}^{-1}$ of body weight) was calculated as the sum of all animal's body weight divided by paddock (repetition) area, being 3.5 ha for $375 \mathrm{DD}$ and 4.0 ha for $750 \mathrm{DD}$.

Animal behavior was evaluated when the animals were on the second occupation day of the cell using five identified animals per cell. Activity time such as grazing, rumination, and resting was measured for $18 \mathrm{~h}$ of the day (7:00 a.m. to 11:59 p.m.), recorded as ten-minute intervals as described by Jochims et al. (2020).

The time spent by animals for herbage selection and apprehension, including the displacement to select a new feeding station, was considered grazing (Hodgson, 1990). The rumination period was identified by the absence of grazing activity and by visual identification of mandibular movements. Time spent in resting activities was considered the time when animals were neither grazing nor ruminating.

Bite rate was measured as the time necessary for the animal to accomplish 20 bites, transformed into bite/min, according to Jamieson and Hodgson (1979). We calculated the number of feeding stations visited per minute, the time spent in each feeding station, and the number of steps between feeding stations based on direct counts for utilization of 10 feeding stations (Ruyle \& Dwyer, 1985). The number of feeding meals through the day was also counted and defined as a continuum grazing period, without interruptions of two or more assessments (20 minutes). Meal duration was calculated as the time between the beginning of the first feeding event and the end of the last feeding event, where intervals between the events were shorter than the meal criterion.

The herbage intake was estimated on four occasions: 12-21 June (autumn), 28 August-6 September (winter), 2-11 December (spring) and 24 March-2 April (Summer). Fecal excretion was estimated from two animals per replicate, using $\mathrm{Cr}_{2} \mathrm{O}_{3}$ (chromium oxide) as an external marker. The adaptation period and collection of feces samples comprised ten consecutive days. $\mathrm{Cr}_{2} \mathrm{O}_{3}$ was provided along with $0.2 \mathrm{~kg}$ of whole rice bran once a day (Kozloski et al., 2006). On the same occasion, to avoid thermal and behavioral discomfort for the animals on 
collection days, a polyethylene external marker was also provided, with different colors for each animal to identify the feces. The polyethylene external marker was made with plastic paper A4 of $0.3 \mathrm{~mm}$ thickness, using a manual machine binder (Excentrix) with $4 \mathrm{~mm}$ diameter. For ten consecutive days, animals were fed $5 \mathrm{~g}$ of $\mathrm{Cr}_{2} \mathrm{O}_{3}$, and in the last three days, the fecal samples were collected from the paddock. $\mathrm{The} \mathrm{Cr}_{2} \mathrm{O}_{3}$ supply started considering the fecal collection when animals were moving into the representative paddocks. For collections, daily "sweeps" were performed. If the polyethylene marker was found, samples were collected. The collected samples were dried until constant weight and afterward ground on $1 \mathrm{~mm}$ sifter.

Fecal chromium concentration was measured by atomic absorption spectrophotometry after acid digestion as described by CzarnockI et al. (1961). Fecal output (FOut) was estimated as:

$$
\text { FOut }=\frac{\text { Supplied } \mathrm{Cr}_{2} \mathrm{O}_{3}(\mathrm{~g} / \mathrm{day})}{\text { Feces }\left[\mathrm{Cr}_{2}\right](\mathrm{g} / \mathrm{kg} \mathrm{DM})}
$$

and intake estimated as:

$$
\text { Intake }(\mathrm{g} / \text { day })=\frac{\text { FOut }(\mathrm{g} / \text { day })}{(1 \text { - Digestibility })}
$$

In situ rumen digestibility of herbage OM (ISRDOD) consumed by animals was determined according to Orskov and McDonald (1979) and hand plucking forage samples collected according to Euclides et al. (1992). The samples were collected in both treatments when the animals were on the second day of occupation. The hand-plucked samples were dried in an oven (BIOMATIC MOD. 1306, Brazil) at $105^{\circ} \mathrm{C}$ for 24 hours and analyzed for total DM, total nitrogen $(\mathrm{N} ; \mathrm{N} \times 6.25$ = crude protein; AOAC, 1990), and neutral (NDF) and acid detergent fiber (ADF) without amylase (Van Soest, 1967).

\subsection{Statistical Analysis}

The data were submitted to a Bartlett test followed by a Shapiro-Wilk test to determine the homogeneity of variances and normality of residuals, respectively. Afterwards the data were submitted to an analysis of variance and $\mathrm{F}$ test. Mean comparison analyses were conducted using PROC MIXED (Tukey test) model procedure of the SAS 9.4 software. Models included the fixed effects of treatments, periods, and the treatment $\times$ period interaction, and the random effect of the paddock (animal group). The best covariance structure was chosen according to the smallest Bayesian Information Criteria, being the autoregressive covariance structure considered.

\section{Results}

No differences were found between treatments for herbage mass evaluations, however, there were differences among seasons throughout the experiment (Table 1). The leaf blade component increased while the dead material decreased during the warmer seasons.

\begin{tabular}{|c|c|c|c|c|c|c|}
\hline Variables & Pregrazing & Herbage Allowance & Leave Blade & Dead Material & Stem & MSR \\
\hline & Kg DM/ha & & | & 6 Pregrazing ---- & 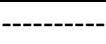 & $\mathrm{Kg} / \mathrm{ha}$ \\
\hline \multicolumn{7}{|l|}{ Treatments } \\
\hline $375 \mathrm{DD}$ & 4100 & 10.61 & 40.6 & 45.9 & 8.4 & 521.5 \\
\hline $750 \mathrm{DD}$ & 4710 & 7.05 & 40.6 & 46.8 & 9.5 & 573.6 \\
\hline SEM & 118 & 0.79 & 1.28 & 1.36 & 0.26 & 26.58 \\
\hline \multicolumn{7}{|l|}{ Season } \\
\hline Autumn & 4283 & 8.29 & $39.6 \mathrm{~b}$ & $47.4 \mathrm{~b}$ & $8.4 \mathrm{c}$ & $484.1 \mathrm{~b}$ \\
\hline Winter & 4912 & 7.93 & $29.9 \mathrm{c}$ & $63.8 \mathrm{a}$ & $3.0 \mathrm{~d}$ & $447.7 \mathrm{~b}$ \\
\hline Spring & 4164 & 8.01 & $45.1 \mathrm{a}$ & $40.2 b c$ & $10.1 \mathrm{~b}$ & $722.6 \mathrm{a}$ \\
\hline Summer & 4260 & 11.09 & $47.7 \mathrm{a}$ & $34.0 \mathrm{c}$ & $14.3 \mathrm{a}$ & $535.7 \mathrm{~b}$ \\
\hline \multicolumn{7}{|l|}{$P$-Values } \\
\hline $\mathrm{T}$ & 0.067 & 0.087 & 0.995 & 0.689 & 0.104 & 0.299 \\
\hline S & 0.127 & 0.126 & 0.000 & 0.000 & 0.000 & 0.000 \\
\hline $\mathrm{T} \times \mathrm{S}$ & 0.112 & 0.913 & 0.128 & 0.383 & 0.865 & 0.083 \\
\hline
\end{tabular}

Table 1. Herbage mass and allowance, sward components of a nature pasture from Pampa biome

Note. $\mathrm{T}=$ treatments; $\mathrm{S}=$ season; $\mathrm{T} \times \mathrm{S}=$ treatments and season interaction; MSR $=$ mean stock rate; $\mathrm{SEM}=$ standard error of the mean. Within columns, means followed by the same letter are not significantly different at $P$ $<0.05$. 
The number of meals, bite rate frequency, feeding time, and steps between feeding stations were similar between treatments and seasons although there was weak evidence $(\mathrm{P}=0.066)$ of differences among seasons in meal frequency (Table 2).

Table 2. Animal behavior of beef heifers grazing in nature pasture

\begin{tabular}{|c|c|c|c|c|c|}
\hline Variables & $\begin{array}{l}\text { Meal Duration } \\
(\mathrm{min} / \mathrm{meal})\end{array}$ & $\begin{array}{l}\text { Meal Frequency } \\
\text { (meals/day) }\end{array}$ & $\begin{array}{l}\text { Bites Rate } \\
\text { (bites/min) }\end{array}$ & $\begin{array}{l}\text { Feeding Time } \\
\text { (feeds station } / \mathrm{min} \text { ) }\end{array}$ & Steps/Feeding Station \\
\hline \multicolumn{6}{|c|}{ Treatments } \\
\hline $375 \mathrm{DD}$ & 82.8 & 6.9 & 39.9 & 6.7 & 1.5 \\
\hline $750 \mathrm{DD}$ & 86.8 & 6.3 & 37.4 & 6.1 & 1.7 \\
\hline SEM & 3.690 & 0.187 & 2.333 & 0.620 & 0.089 \\
\hline \multicolumn{6}{|l|}{ Season } \\
\hline Autumn & 86.6 & 5.9 & 38.4 & 6.3 & 1.6 \\
\hline Winter & 76.7 & 6.6 & 37.6 & 6.0 & 1.7 \\
\hline Spring & 91.3 & 7.7 & 38.0 & 6.0 & 1.6 \\
\hline Summer & 84.7 & 6.5 & 40.5 & 7.2 & 1.6 \\
\hline \multicolumn{6}{|l|}{ P-Values } \\
\hline $\mathrm{T}$ & 0.523 & 0.164 & 0.534 & 0.548 & 0.273 \\
\hline S & 0.321 & 0.066 & 0.774 & 0.138 & 0.818 \\
\hline $\mathrm{T} \times \mathrm{S}$ & 0.296 & 0.198 & 0.193 & 0.340 & 0.468 \\
\hline
\end{tabular}

Note. $\mathrm{T}=$ treatments; $\mathrm{S}=$ season; $\mathrm{T} \times \mathrm{S}=$ treatments and season interaction; $\mathrm{SEM}=$ standard error of the mean.

No differences were observed in chemical composition between treatments and seasons (Table 3).

Table 3. Average values feed intake (FI, \% BW), pasture intake (PI, kg DM/day), supplement intake (SI, $\mathrm{kg}$ $\mathrm{DM} /$ day) of beef heifers and chemical composition (\% DM) of a natural grassland from Pampa biome

\begin{tabular}{|c|c|c|c|c|c|c|c|c|c|c|c|}
\hline \multirow{2}{*}{ Item } & \multicolumn{2}{|c|}{ Treatments } & \multirow{2}{*}{ SEM } & \multicolumn{4}{|c|}{ Periods } & \multirow{2}{*}{ SEM } & \multicolumn{3}{|c|}{$P$-Value } \\
\hline & 375 & 750 & & $21 / 06$ & 06/09 & $11 / 12$ & $02 / 04$ & & $\mathrm{~T}$ & $\mathrm{P}$ & $\mathrm{T} \times \mathrm{P}$ \\
\hline FI & 2.23 & 2.24 & 0.095 & $1.96^{\mathrm{B}}$ & $2.09^{\mathrm{AB}}$ & $2.65^{\mathrm{A}}$ & $2.26^{\mathrm{AB}}$ & 0.137 & 0.965 & 0.050 & 0.533 \\
\hline PI & 1.60 & 2.02 & 0.272 & 1.66 & 1.97 & - & - & 0.224 & 0.389 & 0.307 & 0.908 \\
\hline SI & 1.70 & 1.84 & 0.203 & 1.73 & 1.81 & - & - & 0.145 & 0.685 & 0.228 & 0.856 \\
\hline \multicolumn{12}{|c|}{ Chemical composition (\%) } \\
\hline $\mathrm{CP}$ & 7.93 & 8.01 & 0.403 & 7.55 & 7.58 & 8.15 & 8.61 & 0.437 & 0.896 & 0.317 & 0.580 \\
\hline NDF & 72.64 & 73.29 & 0.893 & 75.16 & 72.83 & 70.18 & 73.68 & 1.221 & 0.638 & 0.147 & 0.833 \\
\hline $\mathrm{ADF}$ & 34.8 & 35.94 & 0.863 & 38.16 & 34.52 & 33.76 & 35.03 & 1.266 & 0.472 & 0.196 & 0.722 \\
\hline DMDIS & 41.34 & 43.59 & 1.149 & $40.96^{\mathrm{B}}$ & $38.28^{\mathrm{AB}}$ & $48.56^{\mathrm{A}}$ & $42.05^{\mathrm{AB}}$ & 1.725 & 0.277 & 0.049 & 0.579 \\
\hline
\end{tabular}

Note. $\mathrm{T}=$ treatments; $\mathrm{P}=$ periods; $\mathrm{T} \times \mathrm{P}=$ treatments and periods interaction; $\mathrm{SEM}=$ standard error of the mean; $\mathrm{CP}=$ crude protein; $\mathrm{NDF}=$ neutral detergent fiber; $\mathrm{ADF}=$ acid detergent fiber; DMDIS $=$ dry matter degradability in situ.

${ }^{\text {A }, ~}{ }^{\text {B }}$ Values within a row with different superscripts differ $(P<0.05)$.

There was no difference in time grazing $(T=0.327)$ and ruminating $(T=0.435)$, between treatments while times periods differed among seasons $(\mathrm{P}=0.004)$ for grazing and $(\mathrm{P}=0.008)$ for ruminating time (Figure 1$)$. 

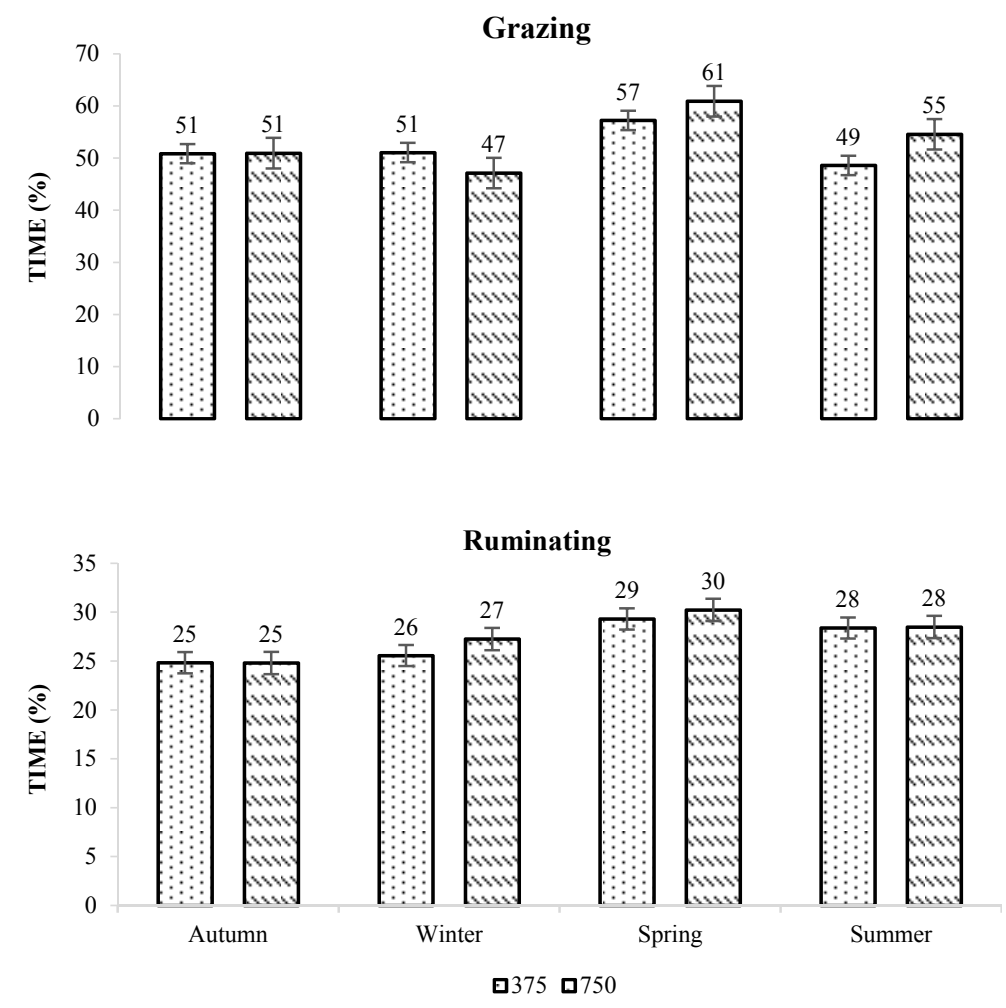

Figure 1. Proportion of time spent by beef heifers (a) grazing, (b) ruminating. Dotted column is $375 \mathrm{DD}$ and stripes backslashes column is $750 \mathrm{DD}$. The error bars represent the standard error mean

The animals spent less time grazing during the cooler winter season when the supplement was around $50 \%$ of feed intake (Table 3). Rumination time showed fluctuation among seasons, being a response to supplementation as grazing time. There is an interaction between treatment and period for resting time $(\mathrm{P}=0.02)$, with lower resting times during spring and summer seasons (Figure 2).

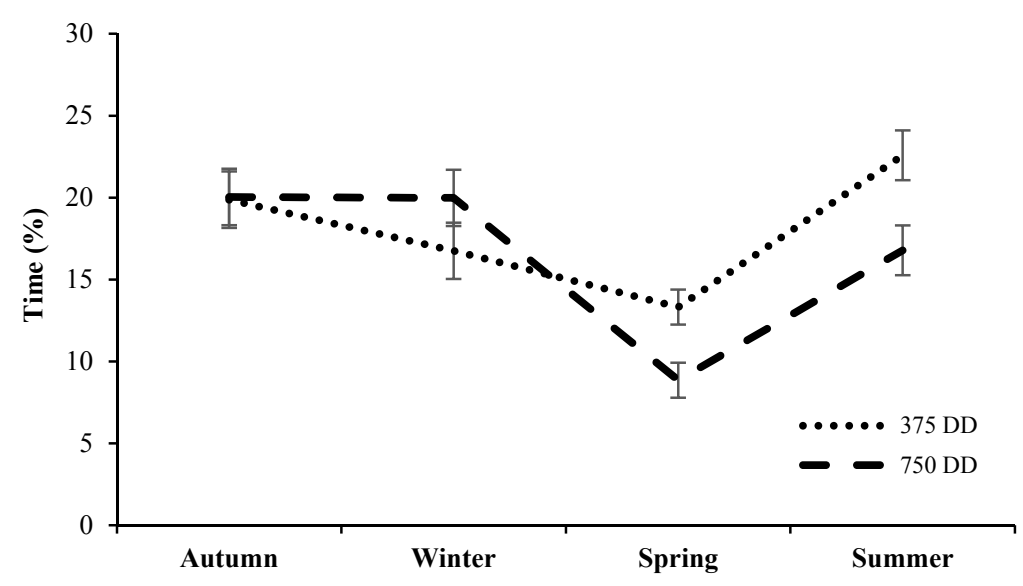

Figure 2. Resting interaction between treatment and period. The error bars represent the standard error mean

The feed intake was similar between treatments; while there was a difference among seasons (Table 3). Pasture and supplement intake were similar between treatments and periods (Table 3); supplement rate was about $50 \%$ of the feed intake. 


\section{Discussion}

This study aimed to evaluate the beef cattle heifer's feeding behavior while the native pasture was managed with two rest intervals under rotational grazing. In our research, the herbage mass (pregrazing) evaluated was higher than other trials in the same natural grassland composition because we calculated the biomass including tussocks, differently than others authors that use only the intertussock area (Da Trintade et al., 2015, Mezalirra et al., 2011, Bremm et al., 2012). Although without difference for herbage mass, the tussocks number is higher in the 750 DD, due to being predominantly composed of Saccharum angustifolium and Aristida laevis.

Herbage allowance did not limit dry matter intake, with values three to four times higher than potential intake, considered non-limiting for animals' feed intake (Sollenberger et al., 2005). However, grazing behavior results indicated that differently from what occurs in cultivated pastures, herbage allowance, or herbage mass did not sufficiently explain the grazing time observed (Pinto et al., 2007). Grassland showed different sward structures among seasons, exhibiting large differences mainly between the winter and summer seasons. This may be confirmed by leave blade and dead material components; leaf blade varied from $30 \%$ during winter to $48 \%$ in the summer, dead material was the opposite, with $64 \%$ in the winter and $34 \%$ in the summer. In our study, even with this fluctuation in sward structure, neither treatment limited the animal behavior. The high herbage allowance maintained in both treatments may be responsible for the lack of influence on animal behavior.

According to Carvalho and Moraes (2005), in swards with non-limiting herbage allowance, animals present a higher number of meals promptly filling their rumen in less time. Our results confirm this assertion; the meal duration (min per meal) was shorter than results previously found by other authors working with a similar grassland composition (Barbieri et al., 2015; Mezzalira et al., 2012). These authors found an average of 118 minutes in similar herbage allowance. Meal frequency (meals per day) was similar to the results from Barbieri et al. (2015) in the same site under rotational grazing and higher than Mezzalira et al. (2012) under continuous grazing with $12 \%$ of herbage allowance.

The bites rate, feeding time (feeds per min), and steps between feed stations were similar to results reported by Barbieri et al. (2015), that found on average 35, 6.0 and 2.9 respectively. The average sward conditions that promoted a high daily forage intake, as well as an increased nutrient intake rate, by cattle grazing natural grassland of the Pampa Biome occurred around 12.1\% BW of forage allowance, characterized by biomass between 1820 and $2280 \mathrm{~kg} \mathrm{DM} \mathrm{ha}^{-1}$ and between 11.5 and $13.4 \mathrm{~cm}$ of height, with tussock levels that did not exceed 30\% (Da Trindade et al., 2015). In our trial, the herbage allowance fluctuated between 8 to $12 \%$; however, this allowance was just from green leaf blades, different from the above-cited authors that evaluated all plant biomass. It is then possible to affirm that the sward structure was not limiting the heifer's feed intake. Favorable herbage allowances, three times the feed intake capacity are frequently associated with high values of herbage intake per bite and slower rates of biting (Hodgson, 1982), probably because ruminants prefer living (growing) to dead (senescent) material, younger to older material, and leaf to stem (Arnold, 1981; Lyons \& Machen, 2000; Gregorini et al., 2015).

On average, time spent on grazing was $50 \%$ in both treatments, Da Trindade et al. (2012) found time spent on grazing to be $43 \%$ during summer and $39 \%$ during the winter season with the best herbage allowance (12\%). However, they evaluated just daylight animal behavior. Barbieri et al. (2015) found $43 \%$ of grazing time in the same area during continuous 24 hours of visual observation. The ruminating time was shorter in our trial than Barbieri et al. (2015); however, we used a lower mean stocking rate used in both treatments, allowing higher selectivity and consequently increasing the grazing time.

The interaction between treatment and season for the proportion of leisure (resting) time can be attributed to the seasonal effect on the composition of the vegetation and its lignification process. The volume of forage mass accumulated until winter is lower in treatment $375 \mathrm{DD}$, which reduces the supply of forage and forces animals to greater effort for its collection, therefore reducing their resting time. In the spring, the accumulated dead material limits the regrowth in the treatment $750 \mathrm{DD}$, forcing the animals to extend the collection time of new regrowth forage and therefore reducing their resting time.

According to Da Trindade et al. (2012), herbage mass from Pampa biome grasslands below $1620 \mathrm{~kg} \mathrm{DM} / \mathrm{ha}$ and $10.1 \mathrm{~cm}$ of height decrease animals' DMI, which cannot be compensated by increasing daily grazing time. This did not occur in our trial; data from vegetation enabled proper conditions for feeding behavior.

Variations in vegetative (sward) characteristics may have a profound effect on grazing behavior. According to Da Trindade et al. (2014), the same herbage allowance may result in different sward structures; when conditions are not favorable for feeding intake, the animal uses compensatory strategies for the ingestive process (Laca, 2008). 
Pasture dry matter intake increased among periods due to DMDIS increase; this showed the same trend that feeds intake, which may be attributed mainly to the higher percentage of green leaf blades recorded during the same period. As there was no difference for feeding behavior variables, dry matter intake was also similar between treatments. Our records were higher than Barbieri et al. (2015) that found $2.04 \% \mathrm{BW}$ under rotational grazing. Da Trindade et al. (2015), in the Pampa biome natural grassland managed with forage allowance levels, reported a similar value in the treatment with of $8 \% \mathrm{BW}$ of forage allowance. However, they used the $\mathrm{C}_{32}$-Alkane as an external indicator.

\section{Conclusions}

Rotational grazing based on ecophisiological traits don't changes ingestive behavior to an insuitable way, allowing favorable conditions to heifers' rearing. The evaluated intervals (375 or $750 \mathrm{DD})$ maintain similar chemical composition on natural grassland. Compared to available regional data, it turns possible to keep higher stocking rates.

\section{Acknowledgements}

The authors would like to thank the Conselho Nacional de Desenvolvimento Científico e Tecnológico (CNPq, Brazil) and the Coordenação de Aperfeiçoamento de Pessoal de Nível Superior (CAPES, Brazil) for scholarship support.

\section{References}

AOAC International. (1990). Official methods of analysis of AOAC International (14th ed.). Association of Analytical Communities, USA.

Barbieri, C. W., Quadros, F. L. F., Jochims, F., Kuinchtner, B. C, Carvalho, T. H. N., Casanova, P. T., ... Pereira, J. B. (2015). Beef heifers grazing behavior and herbage intake in natural grassland under rotational grazing. Ciência Rural, 45, 2056-2062. https://doi.org/10.1590/0103-8478cr20141227

Bengtsson, J., Bullock, J. M., Egoh, B., Everson, C., Everson, T., O’Connor, T., ... Lindborg, R. (2019). Grasslands-More important for ecosystem services than you might think. Ecosphere, 10(2). https://doi.org/10.1002/ecs2.2582

Bremm, C., Laca, E. A., Fonseca, L., Mezzalira, J. C., Elejalde, D. A. G., Gonda, H. L., \& Carvalho, P. C. F. (2012). Foraging behaviour of beef heifers and ewes in natural grasslands with distinct proportions of tussocks. Applied Animal Behaviour Science, 141, 108-116. https://doi.org/10.1016/j.applanim.2012.08.008

Carvalho, P. C. F. (2013). Can grazing behaviour support innovations in grassland management? International Grassland Congress, 1, 1134-1148. https://doi.org/10.17138/tgft(1)137-155

Carvalho, P. C. F., \& Batello, C. (2009). Access to land, livestock production and ecosystem conservation in the Brazilian Campos biome: The natural grasslands dilemma. Livest. Sci., 120, 158-162. https://doi.org/ 10.1016/j.livsci.2008.04.012

Carvalho, P. C. F., \& Moraes, A. (2005). Comportamento ingestivo de ruminantes: Bases para o manejo sustentável do pasto. Manejo sustentável em pastagem (pp. 1-20). Universidade Estadual de Maringá, Maringá.

Czarnocki, J., Sibbald, I. R., \& Evans, E. V. (1961). The determination of chromic oxide in samples of feed and excreta by acid digestion and spectrophotometry. Canadian Journal of Animal Science, 41,167-179. https://doi.org/10.4141/cjas61-024

Da Trindade, J. K., Neves, F. P., Pinto, C. E., Bremm, C., Mezzalira, J. C., Nadin, L. B., ... Carvalho, P. C. F. (2016). Daily Forage Intake by Cattle on Natural Grassland: Response to Forage Allowance and Sward Structure. Rangeland Ecology \& Management, 69, 58-67. https://doi.org/10.1016/j.rama.2015.10.002

Da Trindade, J. K., Pinto, C. E., Neves, F. P., Mezzalira, J. C., Bremm, C., Genro, T. C. M., ... Carvalho, P. C. F. (2012). Forage Allowance as a Target of Grazing Management: Implications on Grazing Time and Forage Searching. Rangeland Ecology \& Management, 65, 382-393. https://doi.org/10.2111/REM-D-11-00204.1

Eggers, L., Cadenazzi, M., \& Boldrini, I. I. (2004). Phyllochron of Paspalum notatum FL. and Coelorhachis selloana (HACK.) camus in natural pasture. Scientia Agricola, 61, 353-357. https://doi.org/10.1590/ S0103-90162004000400001

ELD Initiative. (2015). Report for policy and decision makers: Reaping economic and environmental benefits from sustainable land management. Retrieved from https://www.eld-initiative.org 
Euclides, V. P. B., Macedo, M. C. M., \& Oliveira, M. P. (1992). Avaliação de diferentes métodos de amostragem sob pastejo. Revista Brasileira de Zootecnia, 21, 691-702.

Gordon, I. J. (1995). Animal-based techniques for grazing ecology research. Small Ruminant Research, 16, 203-214. https://doi.org/10.1016/0921-4488(95)00635-X

Gregorini, P., Beukes, P., Waghorn, G., Pacheco, D., \& Hanigan, M. (2015). Development of an improved representation of rumen digesta outflow in a mechanistic and dynamic model of a dairy cow, Molly. Ecological Modelling, 313, 293-306. https://doi.org/10.1016/j.ecolmodel.2015.06.042

Jochims, F., Soares, E. M., Oliveira, L. B., Kuinchtner, B. C., Casanova, P. T., Marin, L., \& Quadros, F. L. F. (2020). Timing and duration of observation periods of foraging behavior in natural grasslands. Frontiers in Veterinary Science, 7, 2297-1769. https://doi.org/10.3389/fvets.2020.519698

Haddock, R., \& Good, K. (2012). Grassland stewardship conservation programming on natural grasslands used for livestock production: Payment for ecosystem services program. Ranchers Stewardship Allience Inc. and Nature Saskatchewan, Canada.

Haydock, K. P., \& Shaw, N. H. (1975). The comparative yield method for estimating dry matter yield of pasture. Australian Journal of Agriculture and Animal, 15, 66-70. https://doi.org/10.1071/EA9750663

Hodgson, J. (1990). Grazing management: science into practice. Longman Scientific \& Technical, Harlow.

Jamieson, W. S., Hodgson, J. (1979). The effect of variation in sward characteristics upon the ingestive behavior and herbage intake of calves and lambs under continuous stocking management. Grass and Forage Science, 34, 273-282. https://doi.org/10.1111/j.1365-2494.1979.tb01479.x

IBGE (Instituto Brasileiro de Geografia e Estatística). (2004). Mapa da vegetação do Brasil e Mapa de Biomas do Brasil. Retrieved April 5, 2020, from https://www.ibge.gov.br/geociencias/cartas-e-mapas/informacoesambientais/15842-biomas.html?=\&t=downloads

Kozloski, G. V., Netto, D. P., Oliveira, L., Maixner, A. R., Leite, D. T., Maccari, M., ... Quadros, F. L. F. (2006). Uso de óxido de cromo como indicador da excreção fecal de bovinos em pastejo: Variação das estimativas em função do horário de mostragem. Ciência Rural, 36, 599-603. https://doi.org/10.1590/S0103-847820 06000200037

Kuinchtner, B. C., Quadros, F. L. F., Casanova, P. T., Marin, L., Seeger, B. B., Steinhorst, D. M., \& Ongaratto, F. (2021). Thermal sum (degrees-days) rest period as a grazing management tool in natural grasslands: Effects on animal performance and forage production. Environmental and Sustainability Indicators, 11, 100-125. https://doi.org/10.1016/j.indic.2021.100125

Laca, E. A. (2008). Foraging in a heterogeneous environment: Intake and diet selection. In V Bels (Ed.), Resource ecology: Spatial and temporal dynamics of foraging (pp. 81-100). CAB International, Wageningen, The Netherlands.

Lyons, R. K., \& Machen, R. V. (2002). Interpreting grazing behaviour. Texas A\&M University System.

Machado, J. M., Rocha, M. G., Quadros, F. L. F., Confortin, A. C. C., Santos, A. B., Sichonany, M. J. O., ... A. T. N. (2013). Morphogenesis of native grasses of Pampa Biome under nitrogen fertilization. Revista Brasileira de Zootecnia, 42, 22-29. https://doi.org/10.1590/S1516-35982013000100004

Martín, J., D. Devincenzi, T., Savian, J. V., Bendersky, D., Moojen, F. G., Pereira, M., ... Lattanzi, F. A. (2021). Native grasslands at the core: A new paradigm of intensification for the campos of southern South America to increase economic and environmental sustainability. Frontiers in Sustainable Food Systems, 5. https://doi.org/10.3389/ fsufs.2021.547834

Mezzalira, J. C., Bremm, C., Trindade, J. K., Nabinger, C., \& Carvalho, P. C. F. (2012). The ingestive behaviour of cattle in largescale and its application to pasture management in heterogeneous pastoral environments. Journal of Agricultural Science and Technology, 2, 909-916. https://doi.org/10.17265/2161-6256/2012. 07A.008

Mezzalira, J. C., Carvalho, P. C. F., Fonseca, L., Bremm, C., Reffatti, M. V., Poli, C. H. E. C., \& Trindade, J. K. (2011). Aspectos metodológicos do comportamento ingestivo de bovinos em pastejo. Revista Brasileira de Zootecnia, 40, 1114-1120. https://doi.org/10.1590/S1516-35982011000500024

Ometto, J. C. (1981). Bioclimatologia vegetal. Agronômica Ceres, São Paulo. 
Ørskov, E., \& McDonald, I. (1979). The estimation of protein degradability in the rumen from incubation measurements weighted according to rate of passage. The Journal of Agricultural Science, 92, 499-503. https://doi.org/10.1017/S0021859600063048

Pinto, C. E., Carvalho, P. C. F., Frizzo, A., Fontoura Júnior, J. A. S., Nabinger, C., \& Rocha, R. (2007). Comportamento ingestivo de novilhos em pastagem nativa no Rio Grande do Sul. Revista Brasileira de Zootecnia, 36, 319-327. https://doi.org/10.1590/S1516-35982007000200007

Provenza, F. D. (2004). Twenty-Five Years of Paradox in Plant-Herbivore Interactions and "Sustainable" Grazing Management. Rang., 25, 4-15. https://doi.org/10.2458/azu_rangelands_v25i6_provenza

Quadros, F. L. F., Garagorry, F. C., Carvalho, T. H. N., Rocha, M. G., \& Trindade, J. P. P. (2011). Utilizando a racionalidade de atributos morfogênicos para o pastoreio rotativo: Experiência de manejo agroecológico em pastagens naturais do Bioma Pampa. Retrieved March 15, 2020, from http://revistas.aba-agroecologia. org.br/index.php/cad/article/view/12716

Quadros, F. L. F., Cruz, P., Theau, J. P., Duru, M., Frizzo, A., Carvalho, P. C. F., Trindade, J. P. P. (2006). Uso de tipos funcionais de gramíneas como alternativa de diagnóstico da dinâmica e do manejo de campos naturais. Reunião Anual da Sociedade Brasileira de Zootecnia, João Pessoa, Brasil.

Ruyle, G. B., \& Dwyer, D. D. (1985). Feeding Stations of Sheep as an Indicator of Diminished Forage Supply. Journal of Animal Science, 61, 349-353. https://doi.org/10.2527/jas1985.612349x

Skinner, R. H., \& Nelson, C. J. (1995). Elongation of the grass leaf and its relationship to the phyllochron. Crop Science, 35, 4-10. https://doi.org/10.2135/cropsci1995.0011183X003500010002x

Sollenberger, L. E., Moore, J. E., Allen, V. G., Pedreira, C. G. S. (2005). Reporting forage allowance in grazing experiments. Crop Science, 45, 896-900. https://doi.org/10.2135/cropsci2004.0216

Streck, E. V., Kämpf, N., Dalmolim, R. S. D., Klamt, E., Nascimento, P. C., \& Schneider, P. (2002). Solos do Rio Grande do Sul (p. 107). Porto Alegre: UFRGS.

Van Soest, P. J. (1967). Development of a comprehensive system of feed analysis and its applications to forages. Journal of Animal Science, 26, 119-127. https://doi.org/10.2527/jas1967.261119x

\section{Appendix A}

Mean Maximum and Minimum Temperature and Mean Rainfall During the Trial

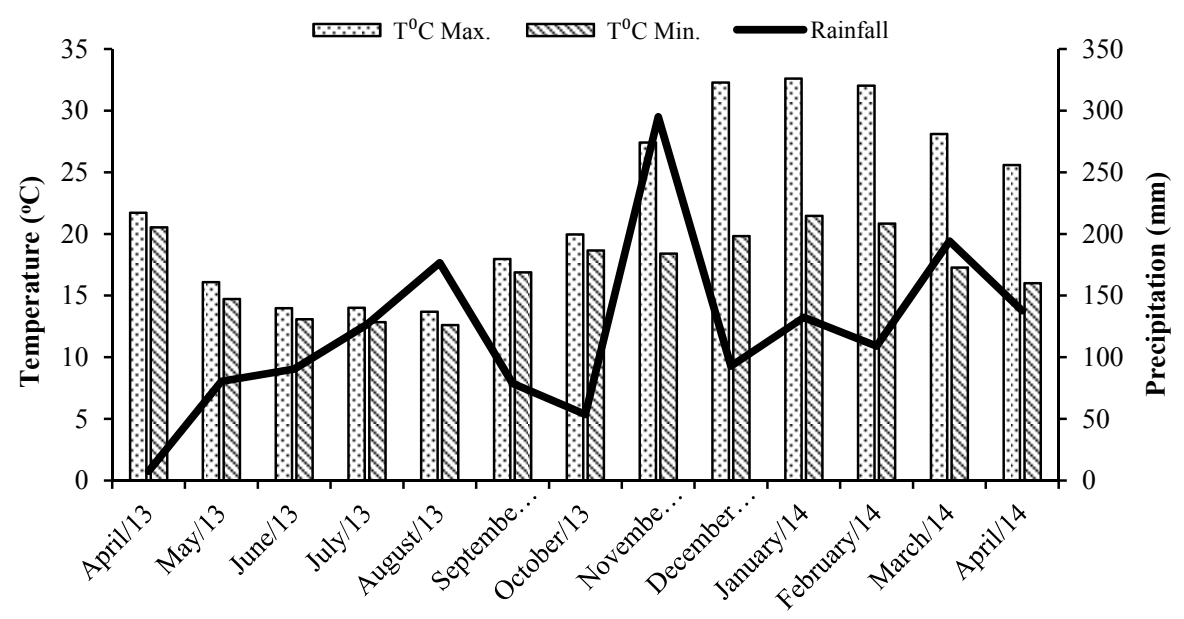




\section{Appendix B}

Arrangement of Experimental Plots and Subplots, First Number Is Plot and Second Number Subplots, Numbers From 11 Until 37 Represent the 375 DD and From 41 Until 67 Correspond the 750 DD Treatment

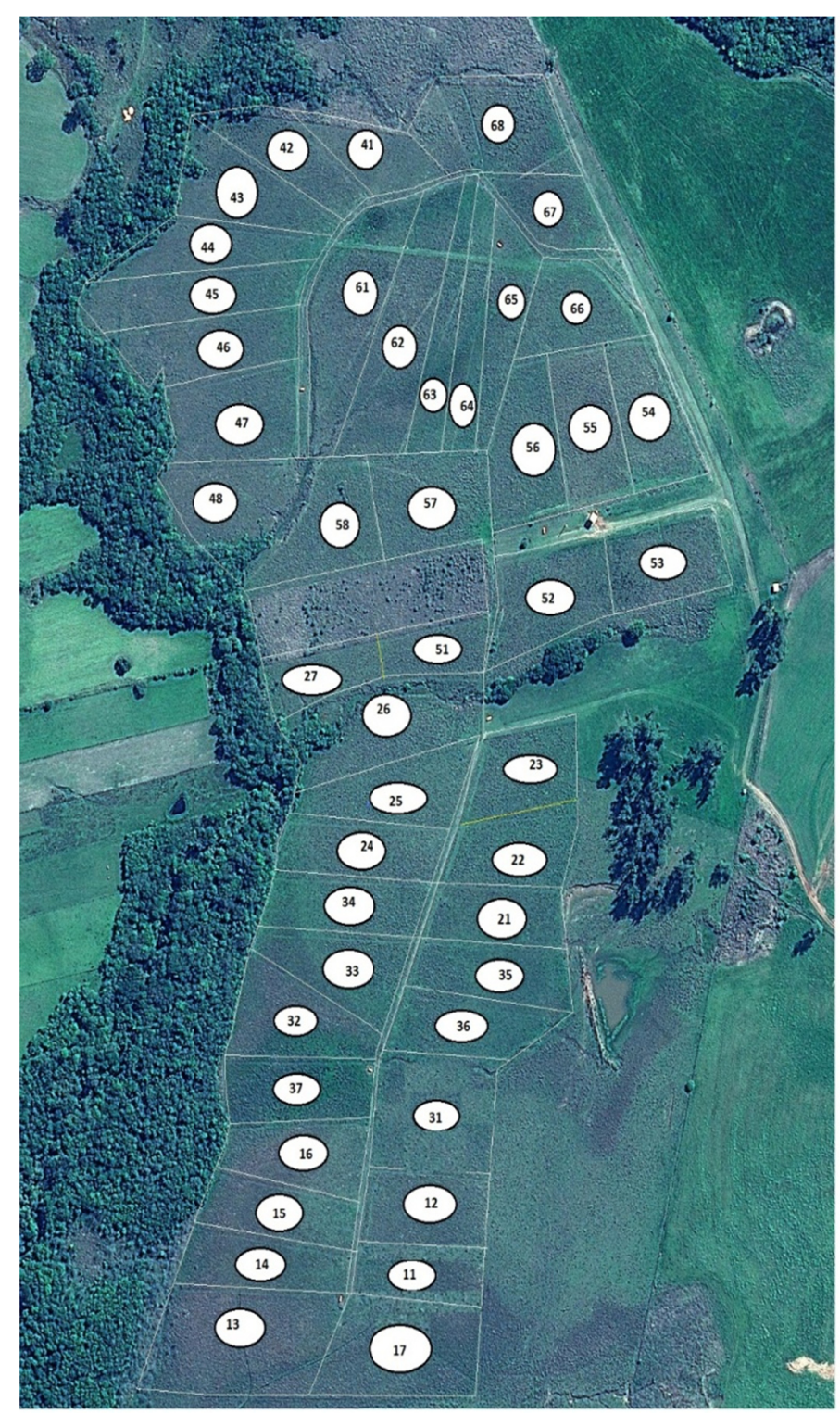

\section{Copyrights}

Copyright for this article is retained by the author(s), with first publication rights granted to the journal.

This is an open-access article distributed under the terms and conditions of the Creative Commons Attribution license (http://creativecommons.org/licenses/by/4.0/). 